\section{Lembaran Sejarah}

\title{
Goresan Imaji dan Narasi Budaya Masyarakat Kawasan Candi
}

\author{
WAHYU PURWIYASTUTI \\ Universitas Kristen Satya Wacana Salatiga; \\ Mahasiswa Program Doktor IImu-IImu Humaniora, FIB UGM \\ Email: purwi_astuti@yahoo.com
}

\begin{abstract}
The Cetho people who live on the slopes of Mount Lawu Karanganyar, have images and cultural narratives. Historical social reality is represented through temple artifacts, house architecture, community service activities, social gathering, etc. This article is a description of the imagination and cultural narratives of the people in the form of oral and written. The results of the culture are packaged in the form of historiography. This article uses qualitative research methods with a cultural history approach. Research, observation and assistance have been carried out since 2011 to 2017. Literacy culture has not been implemented based on standard needs. Therefore, historiographic production is still minimal. The Cetho temple community creates more oral culture. The cultural literacy movement launched by the Ministry of Education and Culture in 2017 has not been fully appreciated. Academics hold a "Live in" program to improve literacy culture. Students write historiography during the "Live in" program in the Cetho temple area. Collaboration and synergy between the community, schools, local government officials, and academics is useful to open opportunities for local cultural literacy education in the national interest.
\end{abstract}

\footnotetext{
Abstrak

Masyarakat Cetho yang tinggal di lereng gunung Lawu Karanganyar, memiliki imaji dan narasi budaya. Realitas sosial historis direpresentasikan melalui artefak candi, arsitektur rumah, aktivitas kerja bakti, arisan, dan lain sebagainya. Artikel ini mendeskripsikan imajinasi dan narasi budaya masyarakat yang berbentuk lisan maupun tulis. Hasil budayanya dikemas dalam bentuk historiografi. Artikel ini menggunakan metode penelitian kualitatif dengan metodologi sejarah kebudayaan yang dilakukan dalam kegiatan riset, pengamatan dan pendampingan sejak tahun 2011 hingga 2017. Budaya literasi masyarakat Cetho belum dilaksanakan berdasarkan standar kebutuhan, sehingga produksi historiografi masih terbilang minim. Masyarakat kawasan candi Cetho lebih banyak menciptakan budaya lisan. Gerakan literasi budaya yang dicanangkan Kementerian Pendidikan dan Kebudayaan pada tahun 2017 belum sepenuhnya diapresiasi. Akademisi menyelenggarakan program "Live in" untuk meningkatkan budaya literasi. Siswa menulis historiografi selama mengikuti program "Live in" di kawasan Cetho. Kolaborasi dan sinergitas antara masyarakat, sekolah, aparat pemerintah, serta akademisi berpeluang melaksanakan pendidikan literasi budaya lokal untuk kepentingan nasional. .
}

\section{Keywords:} education; Central Java; community history; cultural literacy

Kata Kunci: Jawa Tengah; literasi budaya; pendidikan; sejarah komunitas 


\section{Pengantar}

Tapak-tapak langkah terayun menyusuri area pedusunan yang cukup lengang di ketinggian $1496 \mathrm{~m}$ di atas permukaan laut. Ketika itu, akhir Pebruari 2011, tim peneliti yang berlatar belakang pendidikan sejarah mulai mengeksplorasi dusun Cetho. Sebuah dusun kecil di puncak gunung Lawu Kabupaten Karanganyar yang wilayah administrasinya hanya terdiri dari 1 RW dan 3 RT dengan jumlah KK sebanyak 140. Total penduduk yang tercatat di tahun 2011 kurang lebih 436 orang, terdiri dari 211 laki-laki dan 225 perempuan. Mata pencaharian penduduk umumnya bertani sayur. Aktivitas sosial kemasyarakatan warga dusun Cetho berlangsung rukun. Setiap bulan, secara rutin kaum wanita menyelenggarakan pertemuan PKK (Pembinaan Kesejahteraan Keluarga). Di tingkat Rukun Tetangga (RT) dan Rukun Warga (RW) diselenggarakan pertemuan seluruh kepala keluarga.(Wuryani \& Purwiyastuti, Satya Widya, 2012: 150)

Nilai-nilai budaya Jawa (baca Kejawen) dan agama Hindu seolah mengkristal memengaruhi pola hidup masyarakat. Representasi ajaran Hindu dan Kejawen sangat jelas terbaca melalui simbolisasi sikap dan perilaku warga Cetho. Masyarakat kawasan candi itu memelihara kepekaan membaca simbolsimbol mistis yang teragendakan dalam realitas kehidupannya. Sebagaimana diungkapkan beberapa orang tim peneliti yang sedang bermalam di kawasan Cetho, pada tengah malam mereka mendengar suara angin kencang bergemuruh seperti suara pesawat terbang disertai hujan rintik. Keesokan paginya, seorang tim peneliti bertanya pada sang pemilik penginapan terkait peristiwa yang mereka alami. Endah Ngadino sontak menjawab bahwa peristiwa itu sebuah pertanda baik. Dia mempercayai mitos ungkapan alami sikap terbuka leluhur dusun Cetho merespons kedatangan tamu. Tamu yang dimaksud tidak lain adalah rombongan tim peneliti tersebut. Demikian warga dusun memaknai tanda-tanda alam dalam kehidupan mereka. (Purwiyastuti, Suara Merdeka, 2012: 7)

Selain kemampuan membaca tanda alam, masyarakat Cetho pun memaknai kata CETO sebagai singkatan yang sarat makna pendidikan. Huruf "C" sebagai singkatan dari Cepete disudo, "E" adalah Elingono akhirmu, " $T$ " adalah Tenang iku luwih utomo, dan huruf "O" Ora perlu kesusu. Masyarakat Cetho mempercayai bahwa menjalani proses kehidupan tidak perlu ditempuh secara tergesa-gesa, selalu mengingat akan hari esok, dan mengutamakan sikap tenang. Singkatan kata "CETO" itu merupakan salah satu produk pengetahuan budaya yang dihasilkan sekitar tahun 1980-an. (Wuryani \& Purwiyastuti, Satya Widya, 2012: 150) Falsafah hidup CETO sangat arif dan direpresentasikan dalam berbagai aktivitas dan proses hidup masyarakat pemiliknya. Mayoritas produk budaya Cetho masih diproduksi dan direproduksi dalam tradisi tutur.

Geliat kepariwisataan di kawasan candi Cetho mulai terjadi tahun 1983, dan mengalami lonjakkan tingkat kunjungan wisatawan di sekitar tahun 
2013. Data tertulis perkembangan wisatawan itu tidak tersedia karena tradisi historiografi masyarakat Ceto saat itu masih tergolong rendah. Pegawai dinas pariwisata hanya mampu mencatat kunjungan wisatawan secara manual pada buku tulis. Tradisi tutur masyarakat Ceto masih mendominasi karena itu masyarakat sangat terbuka terhadap fasilitasi penelitian dan pendampingan. Berpijak pada kondisi itu, maka tulisan ini sengaja memilih metode penelitian kualitatif dengan pendekatan sejarah kebudayaan dalam rangka mengidentifikasi karya imajinasi, memori, serta narasi lisan maupun tertulis.

Kemampuan menghitung hari baik (ngelmu petung), organisasi sosial arisan warga, ruwatan dusun (tradisi mondhosiyo), kerja bakti di dusun maupun ke arah puncak gunung Lawu, ronda malam, sistem pengairan berbentuk Program Pengairan dan Sanitasi bagi Masyarakat (Pamsimas), kelompok kesenian gamelan Jawa dan seni beganjur, serta upacara agama Hindu merupakan objek amatan dalam riset ini. Berbagai aktivitas tersebut terbukti memperkuat interrelasional antar warga yang secara umum dapat dikatakan minim konflik. Mereka sangat percaya bahwa kawasan candi Cetho merupakan karunia Tuhan yang sangat berharga sehingga masyarakat merasa bertanggungjawab dalam menjaga keamanan dan pelestariannya. Salah satu wujud peran serta masyarakat dalam mengelola kawasan candi adalah dengan menyelenggarakan tradisi ruwatan (lukat). Pemangku adat dusun Cetho memiliki sikap terbuka bagi siapa saja yang mendapatkan wangsit (kedhawuhan), dan melalui seseorang yang kedhawuhan itu pemangku diingatkan untuk meruwat kawasan candi Cetho.(Emy Wuryani, et.al., Tourisma, 2012: hlm. 29)

\section{Menggores Imaji, Menarasikan Produk Budaya}

Artefak candi, arsitektur rumah, guyubnya warga dalam rutinitas kerja bakti setiap minggu pagi, beragam arisan yang sarat nilai sosial ekonomi, serta loyalitas terhadap leluhur sangat masif direpresentasikan dalam realitas sosial historis masyarakat kawasan candi Cetho. Di setiap produk budaya termuat elemen pendidikan yang sarat makna. Terminologi budaya, agama, dan pariwisata mengkristal dalam ritme hidupnya.

Pola konsumsi dan hidup sehat contohnya, dibangun dengan fondasi filosofis nilai-nilai luhur dewi Saraswati. Sosok sang dewi diperoleh dalam upacara Saraswati yang diselenggarakan di puri yang letaknya di sisi timur candi Cetho. Olah intelektual dan imajinasi dikelola menjadi produksi narasi budaya. Berdasarkan hasil wawancara dengan narasumber, disebutkan bahwa mereka termotivasi hidup sehat mengkonsumsi nasi berbahan beras atau jagung, sayur kacang koro, urap daun bribil, kenikir, jelembak, serta lauk bothokan yang berbahan dasar kacang. Daun bribil yang tumbuh di pekarangan rumah dipercaya mengandung asupan gizi tinggi zat besi karena bahan inilah yang digunakan sebagai urap yang melengkapi sesaji atau bancaan 
bagi balita yang berlum mampu berjalan. Berbagai jenis makanan tradisional itu diolah menggunakan tungku dan kayu bakar. Tradisi konsumsi makanan sehat berlangsung efektif hingga tahun 2000-an. Sejak masuknya produk makanan kemasan, masyarakat perlu menuturkan dampak negatifnya kepada anak-anak.(Tarmi, 9 April 2011)

Warga dusun Cetho mengaku lebih banyak melakukan ritual tirakat atau prihatin, mendoakan anak cucunya supaya hidup sejahtera. Salah satu falsafah Jawa yang diangkat adalah "bejane sing eling, cilakane sing ora eling". (Kasmin, 2013) Bagi masyarakat, doa itu paling utama. Sesuai falsafah nama dusun "Ceto" (tanpa huruf "h" di tengahnya. Hidup bernuansa ketenangan dan membersihkan jiwa dari segala godaan hal-hal buruk. Lereng Lawu dipercaya masih alami dan wingit, memiliki daya magis yang sangat tinggi. Warga dusun tidak memiliki keberanian menentang aturan adat setempat. Kondisi ini berimplikasi pada sikap warga untuk selalu konsisten dalam memutuskan sesuatu. Jika "ya" harus konsisten ya, dan jika "tidak" masyarakat pun bersikap keras untuk menolak. Nilai-nilai ini merupakan simbol kesetiaan warga Cetho terhadap leluhurnya. Sikap hormat kepada leluhur hingga kini tidak luntur, sekalipun bagi generasi muda. Konsep sang "Guru" juga merupakan simbolisasi kepatuhannya kepada Sang Khalik. Wignyo (2013), salah seorang warga sesepuh dusun sering dipercaya sebagai pemandu wisata menuju puncak Lawu. Wisatawan sudah mengenal dan mempercayai Wignyo sebagai pemandu ke arah Lawu. Informasi yang diperoleh wisatawan datang dari media promosi lisan antar wisatawan petualang puncak Lawu. Jumlah wisatawan yang dilayani Wignyo semakin meningkat dari waktu ke waktu. Wignyo berargumen bahwa kepercayaan wisatawan kepadanya menunjukkan eksistensi dan keberhasilannya menempuh jalur pendakian yang terkadang penuh tantangan. Seringkali dengan iman Hindu Kejawen, Wignyo menyarankan wisatawan untuk percaya kepada guru sejati yaitu Tuhan, bukan dirinya. Dalam bidang pertanian, apabila kaum muda berniat mengetahui ilmu bertani yang dilakukan orang tuanya, maka dia tidak akan segera mendapatkan jawaban secara langsung. Kaum tua memiliki pemahaman yang kuat yang bersifat turun temurun untuk merahasiakan ilmu bertani yang dikuasai. Mereka tidak dapat sembarangan mewariskan dalam bentuk transfer ilmu terhadap generasi berikutnya. Fenomena ini yang kemudian oleh para pemuda dusun Cetho dimaknai sebagai implementasi nilai-nilai kejawen oleh penganut iman kepercayaan Hindu. Generasi tua menganggap perilakunya sebatas menerapkan petuah leluhur sebagai bentuk loyalitas. Akibat dari kondisi ini, jika anak-anak muda ingin tahu cara-cara bertani, hanya dapat diperoleh melalui nasihat atau petuah yang bersifat arif serta bijaksana.

Realisasi dari konsep "ilmu disengker" memang sarat akan makna dan simbol. Generasi tua selalu mengharapkan generasi mudanya dapat 
mengamati dan mencontoh orang tuanya dalam melaksanakan aktivitas pertanian. Suatu saat jika para pemuda menghadapi kesulitan selama bertani, orang tua secara bertanggungjawab pasti akan memberikan petuah, sekalipun tidak diminta. Dalam representasi ajaran kejawen tersebut, orang tua secara tidak langsung memposisikan diri sebagai seorang "guru" dalam kehidupan masyarakat Cetho. Jika generasi muda tidak berupaya menelusuri pengetahuan ke sumber ilmu atau tidak mencontoh perilaku guru atau leluhurnya, maka ilmu kehidupan tidak akan dimiliki secara sempurna.(Kasmin, 2013) Menurut Sumarto (2012), seorang pamangku Puri Kalisada, ilmu pengetahuan dapat dimiliki oleh seluruh umat dalam segala umur. Petani punya ilmunya sendiri, yaitu ilmu bertani. Para petani sayur di dusun Cetho mempunyai keahlian bertani yang diperoleh dari orang tuanya. Dalam pendidikan non formal inilah mereka menemukan cara-cara menanam, memelihara serta melindungi tanaman dari segala gangguan hama. Ilmu ini tidak pernah diturunkan oleh orang tua mereka.

Rekaman peristiwa yang secara historis penting dalam menyikapi pengaruh global, maka di tahun 2013, komunitas Hindu Cetho secara swadaya membangun sebuah pasraman. Bagunan pasraman yang terletak di halaman rumah pamangku puri Saraswati itu memfasilitasi diselenggarakannya pendidikan informal. Pendidikan pasraman diikuti oleh anak-anak dan remaja umat Hindu Cetho untuk mendalami ajaran agamanya. Agama merupakan unsur mutlak dalam pembangunan karakter bangsa. Agama Hindu, sangat kaya dengan nilai spiritualitas yang relevan dalam pembangunan karakter bangsa guna menghadapi pengaruh nilai-nilai asing pada era globalisasi saat ini yang tidak sesuai dengan karakter bangsa Indonesia.

Menteri Agama, Lukman Hakim Saifuddin, dalam pembukaan Jambore Pasraman Nasional III di Solo juga menjelaskan bahwa pasraman berperan penting dalam membangun karakter generasi muda umat Hindu. Pasraman menanamkan nilai-nilai keagamaan yang menjadi unsur mutlak pembangunan karakter bangsa. Pendidikan keagamaan Hindu yang dilaksanakan pada setiap pasraman di Indonesia memiliki karakteristik yang sangat khas dan berbeda-beda. Kekhususan itu terletak pada diberinya ruang pengaruh adat dan budaya keagamaan yang berkembang di daerah tertentu.(Kompas, 2014, hlm. 12, kolom 1)

Kawasan candi Cetho merupakan representasi ruang menggoreskan imaji dan menarasikan budaya masyarakat. Sejak dahulu saat leluhur Cetho menorehkan karya budaya, hingga sekarang memasuki era global, karya masyarakat Cetho tetap lestari. Di setiap lini proses kehidupan, produk imaji terimplementasikan rapi dan terstruktur. Tradisi menghitung hari baik, perilaku taat beribadah, mengorganisasikan toleransi kehidupan, empati kesejahteraan bersama dalam bentuk arisan, pelestarian lingkungan, dan sebagainya adalah wujud baktinya warga kepada leluhur. 
Selama periode 2011 hingga 2017, produk budaya yang diciptakan oleh masyarakat kawasan candi Cetho masih berbentuk lisan. Mereka belum mendapatkan pemahaman pentingnya memproduksi budaya dalam sebuah media, baik tulis maupun cetak elektronik. Kehadiran akademisi dalam mendampingi masyarakat merupakan poin penting untuk menyosialisasikan fungsi media tertulis dan elektronik. Dalam kondisi tersebut, maka beberapa program seperti riset, pengabdian masyarakat, pendampingan, serta kegiatan studi banding menjadi langkah solutif memobilisasi pola pikir masyarakat agar mampu merespons perubahan di era global. Inventarisasi dan identifikasi masalah semakin intensif dilakukan oleh akademisi dalam rangka memperkenalkan konsep literasi. Program yang intensif mewadahi kegiatan literasi adalah melalui "Live in", siswa dan mahasiswa berkesempatan tinggal bersama masyarakat meski dalam periode yang cukup singkat. Mahasiswa yang memiliki latar belakang pendidikan sejarah berkesempatan memanfaatkan pendampingan mengeksplorasi produk budaya masyarakat dusun Cetho agar dapat diwujudkan dalam beragam karya historiografi.

\section{Tantangan di Era Global}

Sejak tahun 2013, tingkat kunjungan wisatawan menuju kawasan candi Cetho kian melonjak. Ide dan kreativitas masyarakat Cetho pun berkembang pesat merespons geliat pariwisata. Produk budaya lokal berkembang dinamis. Tantangan baru di era global dan milenial disambut positif, terbukti dengan peningkatan fasilitas dan layanan wisata di kawasan candi. Kerjasama antara aparat pemerintah dusun dengan akademisi diwujudkan melalui kesepakatan memfungsikan kawasan Cetho sebagai dusun laboratorium program studi pendidikan sejarah. Keputusan itu sekaligus merupakan respons gerakan literasi budaya yang dicanangkan Kementerian Pendidikan dan Kebudayaan pada tahun 2017. Akan tetapi, sangat disayangkan kesadaran literasi budaya belum dipahami masyarakat.

Idealnya, aparat pemerintahan pusat maupun tingkat dusun, wisatawan, dan akademisi dapat berkolaborsi secara maksimal. Realitasnya, pemanfaatan Dusun Cetho sebagai laboratorium lapangan membutuhkan perjuangan keras. Idealisme gerakan literasi yang masih sangat normatif, senyatanya belum membumi dan bahkan sebagai sebuah panduan budaya ternyata tidak dikenal di tingkat masyarakat. Maka, dalam kondisi ini, sivitas akademisilah yang harus bertugas menjadi mediator mewujudkan idealisme pemerintah. Gerakan literasi budaya yang semestinya mengelaborasi kepentingan pendidikan kesejarahan dalam dimensi nasional jelas masih sangat perlu diberdayakan secara pragmatis fungsional.

Semua aktivitas masyarakat yang dihasilkan sebagai warisan leluhur terekam dalam bentuk lisan maupun tulis bermedia sederhana. Karyo, sering disebut sebagai mbah perjangga, memiliki kemampuan menghitung hari baik. 


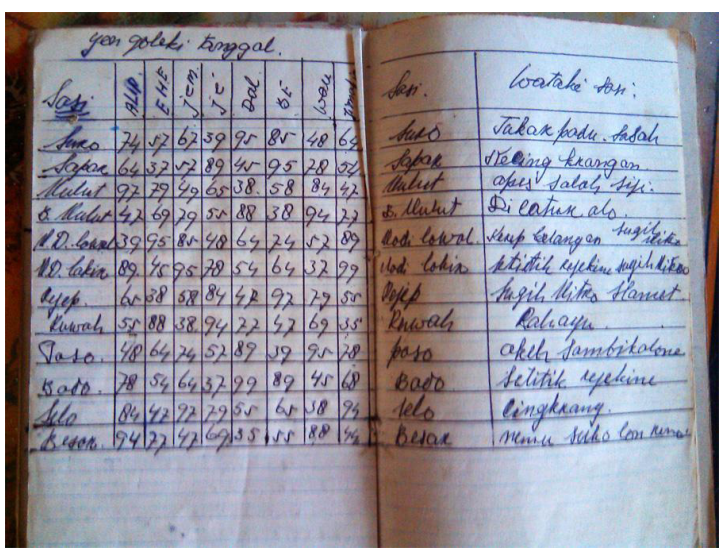

Figur 1. Foto buku koleksi Karyo tentang "Yen Golekki tanggal lan Watak Sasi" (Dok: PS UKSW 2013)

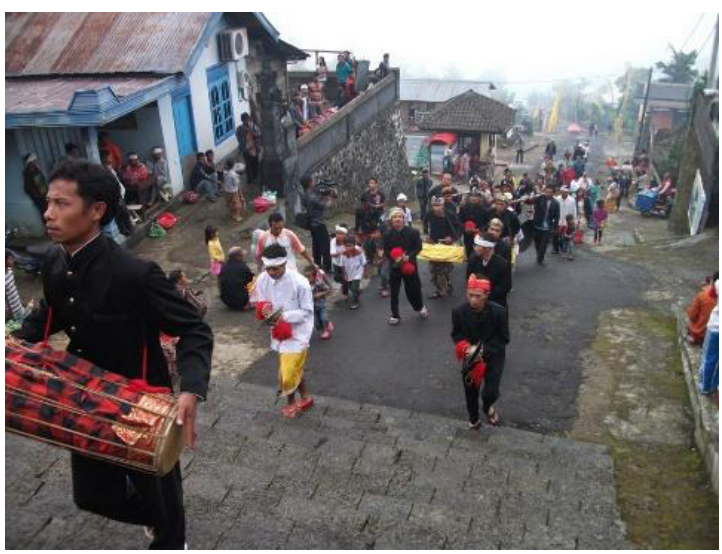

Figur 3. Arak-arakan grup kesenian Beganjur Cetho, simbolisasi respons warga di era global (Dok: PS UKSW 2014)

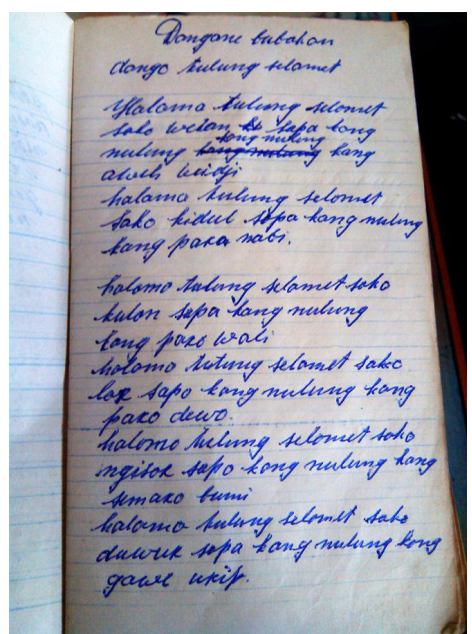

Figur 2. Foto buku koleksi Karyo tentang "Donga tulung selamet" (Dok: PS UKSW 2013)

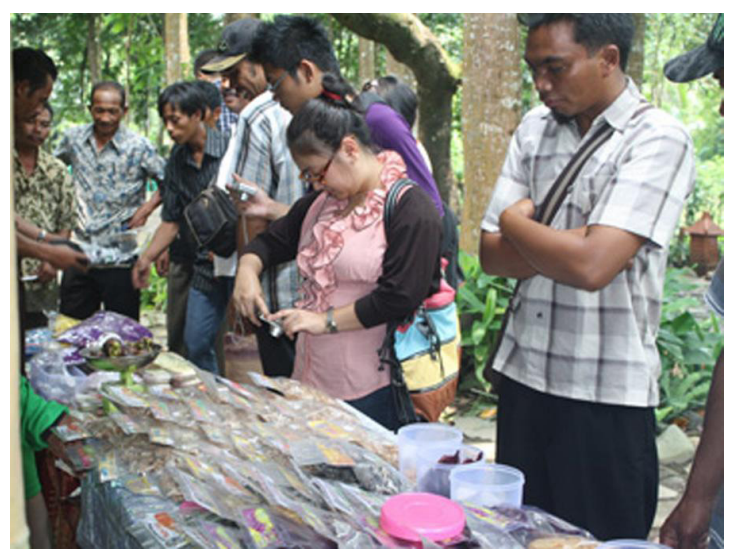

Figur 4. Masyarakat Cetho mengikuti studi banding ke desa wisata Pentingsari, Cangkringan (Dok: PS UKSW2013)

Warga dusun yang akan menyelenggarakan hajatan atau sekedar mengetahui watak, seringkali meminta pertolongan Karyo untuk menghitung waktu. Kemampuan ngelmu petung itu, menurut Karyo diperoleh dari leluhurnya. Karyo mencatat ilmunya dalam sebuah buku catatan kecil, menggunakan pulpen dan kondisi kertasnya sangat rapuh.

Catatan berisi ngelmu petung yang disimpan Karyo, merupakan salah satu bukti rendahnya kemampuan dan kesadaran literasi masyarakat di dusun Cetho. Aktivitas budayanya sangat tinggi, membutuhkan dukungan dan motivasi pihak lain. Akibatnya, produksi dokumen dalam bentuk tulis/ cetak, rekaman foto, atau video sebagai representasi sejarah kebudayaan sangat minim. Figur 3 dan 4 merupakan beberapa contoh rekaman aktivitas masyarakat Cetho ketika menautkan imajinasi kehidupan dengan konteks kehidupan masa kini. Masyarakat semakin kreatif dalam menciptakan 
budayanya. Tradisi upacara Saraswati yang awalnya hanya bersifat monoton, maka sejak 2014 hingga 2017, dikemas dengan prosesi awal arak-arakkan sesaji diiringi tim kesenian beganjur. Kegiatan studi banding ke desa wisata Pentingsari Yogyakarta menjadi ajang membuka wawasan usaha wisata serta menjalin relasi bisnis. Tingginya tingkat kunjungan wisatawan sejak tahun 2014 hingga sekarang, serta kompleksitas dampak era global, bukan ancaman bagi masyarakat kawasan candi Cetho. Mereka siap merespons dengan memproduksi budaya kreatif. Pendampingan yang dilakukan akademisi dari kota Salatiga yang sangat intens mampu memberikan amunisi memasuki era global. Pemberdayaan dusun laboratorium Cetho tetap dilaksanakan, meski tidak terlepas dari berbagai kelebihan dan kekurangan dalam praktik.

\section{Strategi Residensial}

Barangkali langkah Christina Schwenkel (2006) pantas dijadikan referensi. Christina mengusung konsep "Recombinant History: Transnational Practices of Memory and Knowledge Production in Contemporary Vietnam”, yaitu dengan cara mengkolaborasikan konsumsi pariwisata dan praktik memori orang Vietnam. Dia berargumentasi tentang salah satu interrelasi antara masa lalu dan masa depan di Vietnam. Bagaimana dengan produk budaya masyarakat kawasan candi? Apakah mendesak untuk didaur ulang bahkan direproduksi? Bagaimana merealisasikannya?

Riset yang telah berlangsung di kawasan candi Cetho dilakukan dalam ranah pendidikan kesejarahan yang bermuatan teori serta praksis. Akan tetapi, esensi persinggungan konsep pariwisata dan memori sebagaimana disampaikan Christina belum diterapkan secara efektif kepada masyarakat Cetho. Jika Christina mengasumsikan perang dalam sejarah Vietnam sebagai peluang mereproduksi bentuk transnasional memori di sektor yang baru yaitu ekonomi, barangkali riset-riset di kawasan Cetho berikutnya layak mengadopsi gagasan seperti itu. Interrelasi kultur masyarakat candi sebagai representasi imaji yang berkembang melintasi batasan waktu, sangat berpeluang untuk direproduksi. Akan tetapi, dalam konteks tertentu harus dikonsepsikan secara ideologis sistematis. Pendidikan sejarah bisa menjadi unsur penting untuk diberdayakan sebagaimana yang dialami masyarakat kawasan candi Cetho menyikapi kemerebakan sektor pariwisata.

Kuntowijoyo juga menawarkan gagasan tentang sistem pengetahuan yang memiliki relasional erat dengan sistem simbol lainnya dalam pendekatan antropologi simbolis, demikian pula sistem sosial yang kita runut melalui pendekatan sosiologi pengetahuan. Oleh karena itu, Kuntowijoyo pun merekomendasikan agar kendala historiografis dapat diatasi dengan langkah menelusuri karya-karya sejarah kebudayaan yang pernah diproduksi. (Kuntowijoyo, 1994: 113) Tradisi historiografis sejarah kebudayaan masyarakat kawasan candi Cetho jelas masih sangat rendah produktifitasnya. 


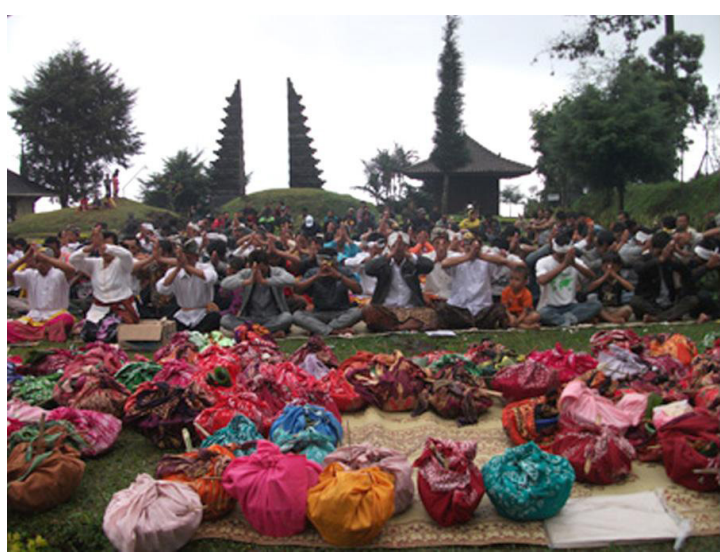

Figur 5. Kepasrahan masyarakat kawasan candi Cetho dalam lahir dan batinnya menjadi fondasi melahirkan karya budaya adiluhung (Dok: PS 2012)

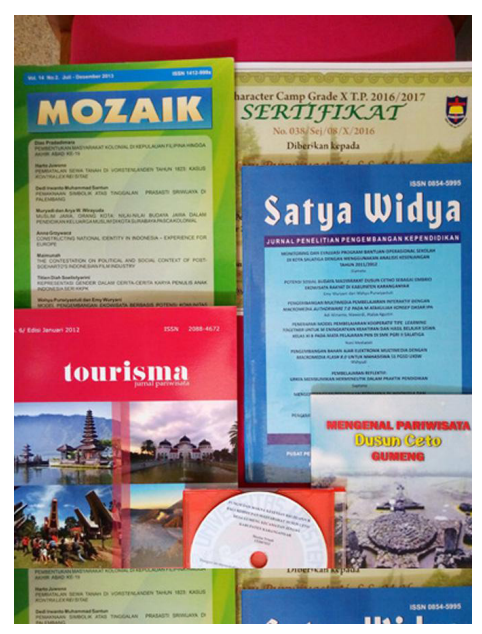

Figur 6. Goresan Imaji \& Narasi Budaya masyarakat kawasan candi Cetho direpresentasikan melalui karya historiografi selama tahun 2012-2017 (Dok: WP)

Sangat diperlukan suatu gerakan khusus menghidupkan etos menarasikan kehidupan masyarakat berbasis peristiwa masa lalu. Akan muncul pertanyaan, mengapa perlu menghidupkan tradisi historiografis masyarakat kawasan candi? Bagaimana merepresentasikan dalam teori dan praksis?

Gambar berikut ini menunjukkan upaya ke arah positif, memacu kesadaran bersama menghasilkan karya historiografi. Hampir semua kegiatan di dusun Cetho berpotensi untuk didokumentasikan. Aksi yang dimulai dengan mendokumentasikan hasil penelitian dosen dan mahasiswa, produk pengabdian masyarakat, maupun rekaman peristiwa yang idenya murni dari masyarakat itu sendiri.

Dalam tataran kebijakan, pemerintah Indonesia pun secara hirarkhis telah merumuskan kebijakan dalam cakupan program pendidikan informal. Strategi gerakan literasi budaya dan kewargaan di sekolah diidealkan sebagai upaya mengembangkan dan memperkokoh beragam aset sejarah dan kebudayaan Indonesia. Beragam lapisan sejarah kebudayaan masyarakat candi dapat diakomodasikan pada celah historiografis yang perlu didokumentasikan. Kuntowijoyo menawarkan pemikirannya yang juga disebutnya sama dengan Huizinga, bahwa tugas sejarah kebudayaan adalah mencari polapola kehidupan, kesenian, dan pemikiran secara bersama-sama. Dalam konteks ini, maka kinerja memproduksi karya historiografis masyarakat candi idealnya didukung aparat pemerintah, masyarakat dalam cakupan luas, sekolah (dan satuan pendidikan), termasuk akademisi. Sistem kolaborasi dan sinergitas itu membuka peluang keberhasilan meliterasi budaya lokal untuk kepentingan nasional. Dalam dimensi birokratis, pemerintah Indonesia melalui kementerian Pendidikan dan Kebudayaan telah merumuskan program literasi budaya sebagai kemampuan memahami dan menyikapi kebudayaan 
Indonesia sebagai identitas bangsa. Konsep itu sering dikorelasikan ketika mengkonstruksi pengetahuan budaya dalam dimensi nasional, yaitu kesadaran kebangsaan yang harus dimiliki setiap warga negara di Indonesia.(Firman Hadiansyah, et. al. 2017: 3)

Artikel ini memublikasikan gagasan agar gerakan residensial yang dicanangkan Kemdikbud berdampak pada meningkatnya produktifitas literasi budaya di Indonesia. Pemanfaatan dusun laboratorium mendesak untuk direnovasi sesuai prosedur, gerakan membaca maupun menulis nantinya dapat menjadi etos yang membudaya, sekolah atau satuan pendidikan serta perguruan tinggi menjadi mitra mendampingi aksi literasi budaya. Kalau Rana Mitter mengasosiasikan museum sebagai media pendidikan patriotik, maka dalam konteks masyarakat kawasan candi, aktivitas budaya dan pariwisata dapat dimanfaatkan sebagai ruang berekspresi. Menurut Rana Mitter, museum sekaligus berfungsi untuk mensponsori publikasi akademis. Esensi memberdayakan museum, dalam riset Mitter disebutkan sebagai mediasi menghubungkan masa lalu dan masa kini. Di era globalisasi, museum di Cina bermanfaat untuk mengingatkan pengunjung terhadap "kondisi rentan pada paham atau isme" yang terjadi masa kini. Siswa diharapkan lebih peka menyikapi kekuatan kooperatif di masa depan.(Ranna Mitter dalam Veronique Benei, 2005, 129-142)

Seiring dengan gagasan Mitter, Martha Caddell juga menempatkan sekolah sebagai tempat membentuk siswa menjadi warga negara dan menjadi wadah terjadinya relasi antar siswa untuk menciptakan relasi dengan kebangsaan. Meski Mitter mengutamakan konsep museum dan Caddell memilih konsep sekolah, namun keduanya menekankan pentingnya wadah atau media pendidikan dalam konteks yang sama. Dalam tulisannya, Caddell menyebutkan bahwa konsep sekolah (merujuk Foucault) menjadi institusi yang paradigmatik, dan pikiran dalam imaji partikuler melalui normalisasi hubungan partikuler dan interaksi. Partisipasi di sekolah dipresentasikan melalui kebijakan pendidikan dan buku teks sebagai latihan. Keduanya digunakan untuk mempromosikan visi kebangsaan. Pendidikan dan pengembangan merupakan unsur yang sangat terkait. Penggunaan terminology "bika" di Nepal merupakan pengantar yang sifatnya sangat mendasar bagi ideologi modern. Bika, bagi masyarakat Nepal digunakan sebagai tanda mobilitas dan basis antara grup dan tempat. Itu semua adalah relasional konsep simbol dari perkembangan yang diasosiasikan lewat grup, individual atau tempat. Sekolah, dalam konteks dan proses aktual kehadiran kelas, ditandai dan dielaborasi sebagai relasi. Artikel Martha terfokus pada interaksi sehari-hari dan praktik pembelajaran di kelas.(Martha Caddell dalam Veronique Benei, 2005, 76-125)

Bagaimana desain gerakan literasi budaya yang ideal bagi masyarakat kawasan candi Cetho? Program "live in" (tinggal bersama masyarakat) yang 
pernah dilaksanakan di kawasan dusun Cetho sejak tahun 2012 hingga sekarang merupakan wadah atau media pendidikan informal yang tepat. Tanggal 12 Juni 2013, kepala pemerintah desa Gumeng didampingi kepala dusun Cetho menerima karya historiografi berjudul "Sejarah Dusun Ceto". (Baca: www.uksw.edu/id.php/info/detail/type/fokus/stamp/1371020716/ Momentum tersebut menjadi penanda awal berlangsungnya gerakan literasi secara formal. Perlu disadari bahwa aktivitas mendokumentasikan karya historiografi di kawasan Cetho penuh dengan kelemahan. Hal itu kemudian senantiasa disadari dengan cara melahirkan beragam gerakan residensial. Salah satu contoh adalah ketika muncul kesepakatan antara tiga perguruan tinggi, yaitu UKSW Salatiga, IKIP Veteran Semarang, dan IKIP PGRI Wates Yogyakarta untuk melaksanakan program Pengabdian Masyarakat di kawasan candi Cetho. Program kolaboratif itu sangat berdampak karena mahasiswa peserta live in berkesempatan menjalin relasi intensif dengan warga Cetho. Pada kegiatan itu, tim perguruan tinggi memotivasi dan memberdayakan potensi seni tradisional yang merupakan potensi lokal. Dalam rangka memperkuat pelestarian seni dan budaya Jawa, dalam kesempatan itu akademisi memberikan stimulan berupa sumbangan buku cerita rakyat, alat permainan tradisional seperti dakon, kostum tari Jawa, serta media cakram digital isinya rekaman cerita dongeng dan legenda. http://www.uksw.edu/ id.php/info/detail/type/fokus/stamp/1430987758/

Pada tingkat satuan pendidikan, live in untuk siswa juga pernah berlangsung di kawasan candi Cetho. Kegiatan itu merupakan kerjasama pengelola laboratorium lapangan Program Studi Pendidikan Sejarah UKSW dengan Sekolah Menengah Atas (SMA) Nasional Plus BPK Penabur Bogor, berlangsung tahun 2016 lalu. Live in yang dikemas sebagai bentuk "Character camp” bagi siswa kelas X dilakukan dalam rangka memperkuat pendidikan karakter siswa. Program ini memilih tema "Pembelajaran kontekstual" untuk mengenalkan siswa SMA Penabur kepada realitas kehidupan sosial masyarakat kawasan candi Cetho. Program itu menekankan penguatan pelaku, aktor, sekaligus fasilitator dengan cara membawa siswa ke suatu komunitas/masyarakat dalam beberapa waktu dengan tujuan mengetahui proses bermasyarakat, berproses, dan berkarya. Siswa tinggal bersama (Live in) di masyarakat dan mengalami langsung sebuah penyesuaian hidup sebagai pengalaman otentik. Selama mengikuti character camp, siswa Penabur terlibat aktif dalam rutinitas hidup masyarakat candi Cetho. Pengalaman yang diperoleh selama lima hari wajib didokumentasikan dalam catatan harian (diary). Siswa yang mayoritas hidup dalam dinamika global bahkan milenial itu, menurut Ari Sekundiarti, sangat diperlukan siswanya. Selama masa jabatannya sebagai kepala sekolah SMA Penabur Bogor, dia sangat gigih mengkampanyekan pengenalan budaya lokal kepada siswa. Harapannya, siswa dapat menuangkan pengalamannya dalam bentuk tulisan dan laku kreatif 
sebagaimana visi literasi budaya di Indonesia.(Ari Sekundiarti, 10 Oktober 2016)

Tanpa menafikkan celah kelemahan secara prosedural, gerakan residensial yang dicanangkan Kemdikbud tahun 2017 merupakan wadah atau media mengapresiasi goresan imaji dan narasi budaya masyarakat kawasan candi. Dalam konteks pragmatis, kelemahan dalam bentuk aturan formal, prosedur operasional lapangan, sanksi, hingga evaluasi, tentu harus terus diupayakan dalam rangka menuju literasi budaya yang berdampak. Gerakan ini menjadi kepedulian bersama dari berbagai pihak agar hasilnya bermanfaat meningkatkan kesejahteraan hidup masyarakat serta memperkokoh rasa kebangsaan.

\section{Kesimpulan}

Interrelasi kultur masyarakat kawasan candi berkembang melintasi batasan waktu, berpeluang untuk direproduksi dan dikonsepsikan secara ideologis maupun sistematis. Sistem pengetahuan memiliki relasional erat dengan sistem simbol. Arsitektur rumah, rutinitas kerja bakti, tradisi bersih desa, upacara keagamaan Hindu, tradisi arisan, rapat Rukun Tetangga (RT) atau Rukun Warga (RW), dan sebagainya adalah simbol budaya yang senyatanya.

Selain itu, sejak tahun 2011 hingga 2017 produksi budaya masyarakat kawasan candi sangat berlimpah dan belum didokumentasikan sesuai standar. Maka, akademisi menyadari hal tersebut dan mulai aktif memediasi reproduksi karya historiografis dengan cara menelusuri karya-karya sejarah kebudayaan yang telah diproduksi masa-masa sebelumnya. Aktivitas itu sekaligus merespons gagasan Kuntowijoyo yang dalam praksis dilengkapi oleh pemikiran Christina Schwenkel, Martha Caddell, serta Ranna Mitter. Terakhir, gerakan residensial dalam kemasan pendidikan kesejarahan bisa menjadi unsur penting untuk memberdayakan masyarakat yang secara khusus berlangsung pada masyarakat kawasan candi ketika menyikapi kemerebakan meningkatnya aktivitas pariwisata.

\section{Daftar Pustaka}

\section{Arsip/Dokumen/Koran/Majalah/Foto}

Firman Hadiansyah, et. al. "Materi pendukung literasi budaya dan kewargaan, Gerakan literasi nasional”. Jakarta: Kementerian Pendidikan dan Kebudayaan, 2017.

Karyo. Rekaman gambar/foto buku petung tentang "Yen Golekki tanggal lan Watak Sasi”. Dokumentasi Program Studi Pendidikan Sejarah, Fakultas Keguruan dan Ilmu Pendidikan, Universitas Kristen Satya Wacana, Salatiga, 2013.

Karyo. Rekaman gambar/foto buku petung tentang "Donga Tulung Slamet". Dokumentasi Program Studi Pendidikan Sejarah, Fakultas Keguruan dan Ilmu Pendidikan, Universitas Kristen Satya Wacana, Salatiga, 2013.

Rubrik Berita "Pendidikan agama, Pasraman berperan bangun karakter". Harian 
Kompas. Halaman 12 Kolom 1-3 edisi Jumat 17 Oktober 2014.

Wahyu Purwiyastuti. Artikel populer "Kearifan dari Ceto". Harian Suara Merdeka.

Halaman 7 Kolom 1 edisi Selasa 4 September 2012.

\section{Buku}

Caddell, Martha. "Discipline makes the nation great visioning development and the nepali nation state throught schools" dalam Benei, Veronique. (ed) Manufacturing Citizenship, Education and Nationalism in Europe, South Asia and China. London: Routledge, 2005. hlm. 76-125.

Kuntowijoyo. Metodologi Sejarah. Yogyakarta: Tiara Wacana, 1994.

Mitter, Ranna. "Educating citizens through war museums in modern China" dalam Benei, Veronique. (ed). Manufacturing Citizenship, Education and Nationalism in Europe, South Asia and China. London: Routledge, 1994. hlm. 129-142.

Schwenkel, Christina. "Recombinant History: Transnational Practices of Memory and Knowledge Production in Contemporary Vietnam". Cultural Anthropology, Vol.21, No. 1. (Feb., 2006), Wiley on behalf of the American, 2006. hlm. 3-30.

\section{Jurnal}

Emy Wuryani, Wahyu Purwiyastuti, Marsono, \& Fahmi Frihantoro. "Pengelolaan Obyek Wisata Kawasan Candi Berbasis Kearifan Lokal”. Tourisma Jurnal Pariwisata. Yogyakarta: Program Studi Pariwisata Fakultas Ilmu Budaya UGM, No 6 Edisi Januari 2012, ISSN 2088-4672.

Emy Wuryani dan Wahyu Purwiyastuti. "Membangun Sinergi Berbasis Kearifan Lokal untuk Pelestarian Benda Cagar Budaya di Kawasan Candi Ceto”. Makalah. Disampaikan dalam Seminar Hasil Penelitian Bekerjasama dengan ASITA Soloraya, Surakarta, 17 Januari 2014.

Emy Wuryani dan Wahyu Purwiyastuti. "Menumbuhkan Peran Serta Masyarakat dalam Melestarikan Kebudayaan dan Benda Cagar Budaya melalui Pemberdayaan Masyarakat”. Jurnal Satya Widya 28 (2), 2012, 147-154. FKIP UKSW.

\section{Media Elektronik}

http://www.uksw.edu/id.php/info/detail/type/fokus/stamp/1371020716/title/ pendidikan-sejarah-gelar-pengabdian-masyarakat-di-dusun-ceto/ (diakses 13-1-2019)

http://www.uksw.edu/id.php/info/detail/type/fokus/stamp/1430987758/title/ pendidikan-sejarah-gelar-pengabdian-masyarakat-di-dusun-laboratorium/ (diakses 13-1-2019)

\section{Wawancara}

Ari Sekundiarti. Wawancara tanggal Oktober 2016. Kepala Sekolah SMA Nasional Plus, BPK Penabur Bogor.

Kasmin. Wawancara tanggal 22 Maret 2013. Pamangku Puri Saraswati dusun Cetho. Sumarto. Wawancara tanggal 2 Juni 2012. Pamangku Puri Kalisada dusun Ceto. Tarmi. Wawancara tanggal 9 April 2011. Ketua PKK Dusun Cetho.

Wiknyo. Wawancara tanggal 23 Maret 2013. Sesepuh dusun, pemandu wisata jalur pendakian Lawu, dan pelaku bisnis penginapan dusun Cetho. 